\title{
URGENSI PEMBELAJARAN AL-QUR'AN HADIST TERHADAP PRESTASI BELAJAR PESERTA DIDIK DI MTS NURUL IKHLAS KALAPA DUA SERAM BAGIAN BARAT
}

\author{
Saddam Husein, Radiudin Alfian Sangadji, Laganti Salayar \\ Email: egy_selayar@yahoo.com
}

\begin{abstract}
Abstrak: Mts Al-lkhlas Kelapa dua, diketahui bahwa peserta didik mempunyai bakat khusus dalam menghafal ayat-ayat juz Amma. Dalam menghafal ayat-ayat juz Amma para peserta didik sering diperlombakan dalam kegiatan hari-hari besar Nabi Muhammad Saw. di MTs AlIkhlas Kelapa dua ini peserta didiknya sangat cerdas dalam menghadapi tantangan dengan peserta didik yang berasal dari sekolah lain. Penelitian ini dilaksanakan di Dusun Kelapa Dua Kecamatan kairatu Kabupaten Seram Bagian Barat. Tipe penelitian ini adalah penelitian kualitatif dengan pendekatan fenomenologi. Metode yang digunaka oleh guru mata pelajaran Al-Qur'an Hadits adalah Metode wahdah, Metode wahda ini yang digunakan dengan cara menghafal satu persatu terhadap ayat-ayat yang hendak dihafalnya. Untuk mencapai hafalan awal, setiap ayat biasa dibaca sebanyak sepuluh kali atau dua puluh kali atau lebih. Sehingga mampu membentuk pola dalam bayangannya. Setelah benar-benar hafal barulah dilanjutkan pada ayat-ayat berikutnya. Untuk mengeksplorasi peserta didik pada MTs AlIkhlas Kelapa Dua sangat pandai dalam penghafalan ayat-ayat suci al-Qur'an, penulis mengambil salah satu prestasi yang di raih peserta didik MTs Al-Ikhlas Kelapa Dua adalah perlombaan yang dilakukan oleh mahasiswa IAIN Ambon untuk meningkatan keimanan dan keilmuan keagamaan pada kalaangan remaja di Dusun Kelapa Dua.
\end{abstract}

Kata Kunci: Urgensi Pembelajaran Al-qur'an Hadist.

\section{PENDAHULUAN}

Pendidikan mempunyai peranan sangat penting dalam keseluruhan aspek kehidupan manusia, karena pendidikan itu berpengaruh langsung terhadap aspek perkembangan dan kepribadian manusia. Dengan pendidikan, diharapkan muncul manusia yang lebih bermutu, dan mampu membangun masyarakatnya. Oleh karena itu, tujuan, isi dan proses pendidikan harus disesuaikan dengan kondisi, karakteristik, kekayaan, dan perkembangan masyarakat itu sendiri. (Ismail DP, 2009: 8) 
Pendidikan adalah aktivitas dan usaha manusia untuk meningkatkan kepribadiannya dengan jalan membina potensi-potensi pribadinya, yaitu rohani (pikir, karsa, rasa, cipta dan budi nurani). Pendididkan juga berarti lembaga yang bertanggungjawab menetapkan cita-cita (tujuan) pendidikan, isi, sistem dan organisasi pendidikan. Lembaga-lembaga ini meliputi keluarga, sekolah dan masyarakat.

Driyarkara mengatakan bahwa pendidikan adalah upaya memanusiakan manusia muda. Pengangkatan manusia ke taraf insani itulah yang disebut mendidik. (Driyarkara, 2009: 103) Menurut Rousseau Pendidikan adalah memberi kita perbekalan yang tidak ada pada masa anakanak, akan tetapi kita membutuhkannya pada waktu dewasa.( Rousseau, 2000: 67).

Pendidikan, seperti sifat sasarannya yaitu manusia, mengandung banyak aspek dan sifatnya sangat kompleks. Sebagai proses transformasi budaya, pendidikan diartikan sebagai kegiatan pewarisan budaya dari generasi satu ke generari yang lain. Sebagai proses pembentukan pribadi, pendidikan diartikan sebagai suatu kegiatan yang sistematis dan sistemik terarah kepada terbentuknya kepribadian peserta didik.

Pendidikan Islam adalah bimbingan jasmani, rohani berdasarkan hukum- hukum agama Islam menuju kepada terbentuknya kepribadian utama menurut ukuran-ukuran Islam. Dengan pengertian yang lain sering kali beliau mengatakan kpribadian utama tersebut dengan istilah kepribadian muslim, yaitu kepribadian yang memiliki nilai- nilai agama Islam, memilih dan memutuskan serta berbuat berdasarkan nilai- nilai Islam, dan bertanggung jawab sesuai dengan nilai- nilai Islam. Dari defenisi ini, tampak adanya perhatian kepada pembentukan kepribadian anak yang menjadikannya 
memikir, memutuskan, berbuat dan bertanggung jawab sesuai dengan nilainilai Islam, (Ahmad D. Marimba, 2007: 12).

Pendidikan agama Islam adalah pendidikan dengan melalui ajaranajaran Islam, yaitu berupa bimbingan dan asuhan terhadap anak didik agar nantinya setelah selesai dari pendidikan ia dapat memahami, menghayati dan mengamalkan ajaran- ajaran agama Islam yang telah diyakininya secara menyeluruh, serta menjadikan agama Islam itu sebagai suatu pandangan hidupnya demi keselamatan dan kesejahteraan hidup di dunia maupun di akhirat kelak. Pendidikan agama merupakan bagian pendidikan yang amat penting yang berkenaan dengan aspek-aspek sikap dan nilai, antara lain akhlak dan keagamaan. Oleh karena itu pendidikan agama juga menjadi tanggung jawab keluarga, masyarakat dan pemerintah.

Mts Al-Ikhlas Kelapa dua, diketahui bahwa peserta didik mempunyai bakat khusus dalam menghafal ayat-ayat juz Amma. Dalam menghafal ayatayat juz Amma para peserta didik sering diperlombakan dalam kegiatan harihari besar Nabi Muhammad Saw. di MTs Al-Ikhlas Kelapa dua ini peserta didiknya sangat cerdas dalam menghadapi tantangan dengan peserta didik yang berasal dari sekolah lain. Dan dalam prestasinya dapat meningkat dalam proses pembelajaran. namun potensi tersebut belum dioptimalkan secara baik.

Latar belakang inilah yang mendorong penulis untuk melakukan penelitian mengenai pembelajaran al-qur'an hadist terhadap prestasi peserta didik di MTs Nurul Ikhlas Kalapa Dua, meliputi pola pendidikan baik mengenai metode, konsep, kurikulum, strategi, serta hal-hal yang berkatian dengan aktifitas pembelajaran al-qur'an hadist dalam upaya mendidik potensi peserta didik tersebut.

Adapun tujuan dari penelitian ini adalah: 
1. Untuk mengetahui cara dan metode menghafal al-Qur'an terhadap prestasi belajar.

2. Untuk mengetahui eksplorasi atau kemampuan peserta didik dalam menghafal al-Qur'an, dan.

3. Mengetahui bagaimana dampak menghafal.

\section{Pengertian Bakat}

Bakat adalah potensi diri seorang peserta didik yang dengan adanya rangsangan tertentu memungkinkan orang tersebut mencapai suatu tingkat kecakapan, pengetahuan, dan keterampilan khusus, (Dimyati dan Mudjiono, 2009: 237). Bakat juga dapat diartikan sebagai suatu kelebihan atau keunggulan alamiah yang melekat pada diri seseorang dan menjadi pembeda antara orang itu dengan orang lain. Misalnya bakat dalam menghafal alqur'an. Inilah yang dapat membedakan seseorang dengan orang lain.

Adapun pengertian bakat menurut para ahli adalah berikut :

a. S.C. Utami Minandar (Elizabeth B. Hurlock)

Bakat pada umumnya diartikan sebagai kemampuan bawaan, sebagai potensi yang masih perlu dikembangkan dan dilatih agar dapat terwujud.

b. Kartini Hartono (dalam bukunya Agus Sudjanto)

Bakat adalah mencakup segala faktor yang ada pada individu sejak awal pertama dari kehidupannya, yang kemudian menumbuhkan perkembangan keahlian, kecakapan dan ketrampilan khusus tertentu

c. Suganda Pubakawatja (dalam bukunya Kurt Singer)

Bakat sebagai benih-benih dari suatu sifat yang baru akan nampak nyata jika mendapat kesempatan atau mungkin untuk berkembang. 
Berdasarkan definisipara ahli tersebut, maka dapat disimpulkan bahwa:

Bakat merupakan kemampuan bawaan, sebagai potensi yang masih perlu dikembangkan dan dilatih agar dapat terwujud, Bakat tidaklah diturunkan semata, tetapi merupakan interaksi dari faktor keturunan dan faktor lingkungan, artinya di bawah sejak lahir berupa potensi dan berkembang melalui proses belajar, dan memiliki ciri khusus, Orang yang berbakat dalam bidang tertentu diperkirakan akan mampu mencapai prestasi dalam bidang itu. Bakat juga dapat didefenisikan sebagai kondisi kualitas, atau sekumpulan kualitas, pada diri individu untuk menunjukan sampai dimana dia akan mampu mendapatkan latihan yang cocok untuk mengembangkan kualitas tersebut dan bakat juga merupakan prestasi yang dapat diramalkan dan dapat diukur melalui tes khusus.

Oleh karena itu bakat dapat dikategorikan sebagai suatu kemampuan yang memiliki tiga arti.

1. Achievment, yang merupakan kemampuan aktual tertentu yang dapat diukuralat tes tertentu.

2. Capacity, yang merupakan kemampuan potensial, yang dapat diukur secara tidak langsung dengan melalui pengukuran terhadap kecakapan individu, dimana kecakapan ini berkembang dengan perpaduan antara dasar latihan yang intensif dengan pengalaman.

3. Aptitude, yaitu kualitas yang hanya dapat diungkap atau diukur dengan tes khusus yang sengaja dibuat.( Ikhwanudin, 2016)

Dari barbagai macam pengertian di atas para ahli sendiri mempunyai pandangan yang berbeda-beda dalam menganalisa bakat. Namun demikian pada umumnya mereka sependapat bahwa analisis terhadap bakat selalu seperti analisis psikologis yang lain, yakni analisis tentang tingkah laku. 
Analisis tersebut menunjukkan bahwa di dalam tingkah laku terdapat tiga hal yang selalu berhubungan, yakni:

a. Bahwa individu melakukan sesuatu,

b. Bahwa apa yang dilakukan merupakan sebab atau alasan bagi hal tertentu,

c. Bahwa dia melakukan sesuatu dengan cara tertentu.

Tiga aspek tingkah laku Dari hal di atas dapat disimpulkan bahwa tingkah laku mengandung tiga aspek, yakni:

1. Aspek tindakan (performence),

2. Aspek sebab akibatnya (a person causes a result),

3. Aspek ekspresif.

\section{Pengertian Prestasi Belajar}

Prestasi adalah hasil dari suatu kegiatan yang telah dikerjakan, diciptakan baik secara individu maupun kelompok. Prestasi tidak akan pernah dihasilkan selama seseorang tidak pernah melakukan sesuatu kegiatan. Pencapaian prestasi tidaklah mudah, akan tetapi kita harus menghadapi berbagai rintangan dan hambatan hanya dengan keuletan dan optimis dirilah yang dapat membantu untuk mencapai.27Kata prestasi belajar terdiri dari dua suku kata, yaitu prestasi dan belajar.Di dalam Kamus Besar Bahasa Indonesia, yang dimaksud dengan prestasi belajar yaitu hasil yang telah dicapai (dilakukan, dikerjakan, dan sebagainya). (KKB, 2002: 895)

Ada juga yang mengartikan prestasi sebagai hasil belajar yang dicapai oleh peserta didik setelah menjelani serangkaian proses belajar mengajar. Kemampuan intelektual peserta didik sangat menentukan keberhasilan peserta didik dalam memperoleh prestasi.Untuk mengetahui berhasil dan 
tidaknya seseorang dalam belajar, maka perlu dilakukan suatu evaluasi. Tujuannya untuk mengetahui prestasi yang diperoleh peserta didik setelah proses belajar mengajar berlangsung.

Selanjutnya untuk memahami pengertian tentang belajar berikut dikemukakan beberapa pengertian belajar diantaranya menurut Slameto dalam bukunya Belajar dan faktor-faktor yang mempengaruhinya bahwa belajar ialah suatu usaha yang dilakukan seseorang untuk memperoleh suatu perubahan tingkah laku yang barusecara keseluruhan, sebagai hasil pengalamannya sendiri dalam interaksi dengan lingkungannya. Muhibbin Syah mendefenisikan belajar adalah tahapan perubahan seluruh tingkah laku individu yangrelative menetap sebagai hasil pengalaman dan interaksi dengan lingkungan yang melibatkan proses kognitif. Begitu juga menurut James Whitaker yang dikutip oleh Wasty Soemanto belajar adalah proses dimana tingkah laku ditimbulkan atau diubhah melalui latihan dan pengalaman. Berdasarkan beberapa pendapat di atas bahwa belajar merupakan kegiatan yang dilakukan secara sadar dan rutin pada seseorang sehingga akan mengalami perubahan secara individu baik pengetahuan, keterampilan, sikap dan tingkah laku yang dihasilkandari proses latihan dan pengalaman individu itu sendiri dalamberinteraksi dengan lingkungannya. (Sunartombs, 2016)

Berdasarkan beberapa pendapat di atas dapat disimpulkan bahwa belajar merupakan kegiatan yang dilakukan secara sadar dan rutin pada seseorang sehingga akan mengalami perubahan secara individu baik pengetahuan, keterampilan, sikap dan tingkah laku yang dihasil kandari proses latihan dan pengalaman individu itu sendiri dalam berinteraksi dengan lingkungannya. 


\section{HASIL PENELITIAN}

Prestasi belajar adalah hasil dari proses belajar yang berupa perubahanperubahan dalam bidang pengetahuan atau pengalaman, dalam bidang ketrampilan, dalam bidang sikap dan nilai seseorang dalam belajar. (WS Winkel, 1984: 102)

Berikut petikan wawancara dengan salah seorang guru bidang studi AlQur'an Hadits, guru mengaji dan kepala sekolah pada MTs Al-Ikhlas Kelapa Dua di Dusun Kelapa Dua terkait dampak mengfal al-qur'an terhadap pretasi belajar di sekolah.

- A. R. Narahaubun / guru bidang studi

Menurut saya prestasi belajar merupakan salah satu hal yang penting untuk diperhatikan, Karena berhasil tidaknya suatu pendidikan di sekolah dapat diketahui melalui prestasi belajar yang diperoleh oleh anak-anak kita. Banyak orang yang bilang bahwa prestasi belajar itu adalah nilai-nilai yang dimiliki oleh anak-anak di sekolah. Pandangan yang demikian menurut saya terlalu sempit, dimana prestasi belajar itu bukan hanya membicarakan tentang nilai melainkan juga semua perubahan dalam bidang pengetahuan, ketrampilan dan juga sikap anak-anak dalam belajar.

- Ny. Maryam Narahaubun / guru mengaji

Kalau saya, Menghafal al-Quran merupakan kebutuhan Umat Islam sepanjang zaman. Masyarakat tanpa penghafal al-Quran akan sepi dari suasana al-Qur'an yang semarak. Oleh karena itu pada zaman Rasulullah SAW mereka yang menghafal al-Quran akan mendapat kedudukan yang khusus. Tanpa menghafal Al-Quran dan mengamalkannya, umat Islam tidak akan meraih kembali izzahnya. Karena al-Quran diturunkan dengan hafalan bukan dengan tulisan, maka setiap ada wahyu yang turun Nabi menyuruh menulisnya dan menghafalkannya. Nabi menganjurkan supaya al-Quran itu dihafal, selalu dibaca dan diwajibkan membaca dalam shalat, sehingga dengan demikian al-Quran terpelihara keaslian dan kesuciannya. 
- A. Taharob / kepala sekolah MTs Al-Ikhlas Kelapa Dua

Menurut saya, Dapat difahami bahwa indikasi tinggi atau rendahnya prestasi belajar yang diraih oleh katong pung anak-anak peserta didik di sekolah MTs Al-Ikhlas Kelapa Dua bukan semata diukur pada nilai yang diperoleh dalam ujian yang dilaksanakan, tetapi terletak pada keseluruhan perubahan yang terjadi pada anak-anak. Dengan kata lain, tingginya nilai yang ditempuh oleh seorang anak-anak dalam seluruh mata pelajaran belum dapat dikatakan telah memperoleh prestasi yang baik, sebelum terjadinya perubahan yang signifikan pada diri anak didik dari sikap yang kurang baik kepada sikap yang lebih baik.

Kesimpulan peneliti adalah banyak faktor yang mendukung tercapainya prestasi bagi seorang peserta didik. Secara umum terdapat dua faktor yang dapat mempengaruhi prestasi belajar seorang anak didik, yaitu faktor yang berasal dari dalam diri peserta didik (intern) dan faktor yang berasal dari luar diri peserta didik (ekstern). Faktor intern antara lain berupa bakat, minat, intelegensi dan sebagainya. Sedangkan faktor ekstern misalnya faktor lingkungan masyarakat, lingkungan keluarga dan sebagainya.

Berikut wawancara bersama beberapa siswa yang berasal dari sekolah MTs Al-Ikhlas Kelapa Dua

- Asti K. Rahayaan (salah seorang siswa kelas VII MTs Al-Ikhlas Kelapa Dua)

Alhamdulillah katong sekarang bisa membaca al-Qur'an, karena dari katong pung guru mengaji dan katong pung guru-guru di sekolah, katong sering di perlombakan ditingkat kelas maupun di tengkat sekolah, atau ada acara-acara halal bi halal katong sering di perlombakan oleh kaka-kaka panitia halal bi halal, disitu katong perlombakan ayat-ayat al-Qur'an.

Alhamdulillah syukur juga, katong paling di[perhatikan oleh guru mengaji dan katong pung guru-guru di sekolah MTs Al-Ikhlas Kelapa Dua, katong 
[pung guru-guru di sekolah bilang katong harus rajin mengaji suapaya kating bisa sekolah tarus sampe ke perguruaan tinggi lainnya, Amin

- Nabila Muhammad (salah seorang siswa kelas VIII MTs Al-Ikhlas Kelapa Dua)

lya, katong sangat bersukur sebagai katong siswa - siswi MTs Al-Ikhlas Kelapa Dua, karena katong bisa baca dan menulis al-Qur'an di depan papan tulis maupun di buku, itu samua dari katong pung guru-guru yang ajar katong untuk kedepan yang labih baik.

Katong pung orang tua serahkan penuh di guru megaji untuk belajar katong baca al-Qur'an yang baik dan benar, katong sangat paling bersukur, katong orang tua sudah kasi sekolah katong sampe sudah MTs, guru-guru di sekolah mengajar katong untuk bagimna bisa menghafal dan membaca alQur'an yang baik dan benar.

- Zahwa Khabiza Said (salah seorang siswa kelas IX MTs AI-Ikhlas Kelapa Dua)

Katong paling sering ikut lomba mebaca ayat-ayat al-Qu'an di tingkat kelas, sekolah unggul lainnya dengan katong sandiri di dalam kampung, misalanya adanya acara - acara hari besar islam, katong pung guru-guru sandiri yang jadi juri untuk memperhatikan katong pung cara baca dengan katong pung cara hafalan yang baik dan benar.

Setelah katong sering diperlombakan, guru-guru mengaji akan mengevaluasi katong di tempat pengajian, terkait katong pung kesalahankesalahan yang katong keliru pada saat katong ikut lomba timgkat sekolah maupun tingkat lainnya.

Dari hasil wawancara yang peneliti ambil dari beberapa petika dari masing masing peserta didik pada MTs Al-Ikhlas Kelapa dua Kecamat Kairatu Kabupaten Seram Bagian Barat.

Peserta didik pada MTs Al-Ikhlas Kelapa Dua sangat pandai dalam mengeksplorasi penghafalan ayat-ayat suci al-Qur'an, penulis mengambil 
salah satu prestasi yang di raih peserta didik MTs Al-Ikhlas Kelapa Dua adalah perlombaan yang dilakukan oleh mahasiswa IAIN Ambon untuk meningkatan keimanan dan keilmuan keagamaan pada kalaangan remaja di Dusun Kelapa Dua pada bulan Ramadhan kemarin, pasca lebaran Idul Fitri itu termasuk peserta didik MTs Al-Ikhlas Kelapa Dua sangat aktiv dalam perlombaan ini karena didalamnya adalah ada perlombaan ayat-ayat suci alQur'an.

Berhasil tidaknya suatu pendidikan di sekolah dapat diketahui melalui prestasi belajar yang diperoleh oleh peserta didik. Banyak orang yang menganggap bahwa prestasi belajar itu adalah nilai-nilai yang dimiliki oleh peserta didik di sekolah. Pandangan yang demikian menurut penulis terlalu sempit, dimana prestasi belajar itu bukan hanya membicarakan tentang nilai melainkan juga semua perubahan dalam bidang pengetahuan, ketrampilan dan juga sikap seorang peserta didik dalam belajar.

\section{KESIMPULAN}

Berdasarkan pembahasan di atas, yang menjadi pokok permasalahan bagaimana dampak menghafal al-qur'an terhadap prestasi belajar (studi pada MTs Al-Ikhlas Kelapa Dua), selanjutnya penulis bagi dalam beberapa kesimpulan sebagai berikut:

4. Metode wahdah Metode ini digunakan dengan cara menghafal satu persatu terhadap ayat-ayat yang hendak dihafalnya. Untuk mencapai hafalan awal, setiap ayat biasa dibaca sebanyak sepuluh kali atau dua puluh kali atau lebih. Sehingga mampu membentuk pola dalam bayangannya. Setelah benar-benar hafal barulah dilanjutkan pada ayatayat berikutnya. Dengan cara yang sama, demikian seterusanya hingga mencapai satu muka. Setelah ayat-ayat dalam satu muka telah dihafalnya, maka giliran menghafal urutan-urutan ayat dalam satu muka. 
5. Peserta didik pada MTs Al-lkhlas Kelapa Dua sangat pandai dalam mengeksplorasi penghafalan ayat-ayat suci al-Qur'an, penulis mengambil salah satu prestasi yang di raih peserta didik MTs Al-lkhlas Kelapa Dua adalah perlombaan yang dilakukan oleh mahasiswa IAIN Ambon untuk meningkatan keimanan dan keilmuan keagamaan pada kalaangan remaja di Dusun Kelapa Dua.

6. Hasil penelitian menunjukkan bahwa Dampak Menghafal al-Qluran, Motivasi Belajar peserta didik, secara Bersama-sama terhadap Prestasi Belajar prestasi didik MTs Al-Ikhlas Kelapa Dua.

\section{DAFTAR PUSTAKA}

[1] Agustin Risa, Kamus Ilmah Populer, (Surabaya : Serba Jaya),

[2] Djumaeda Siti, Evaluasi Pendidikan, (Jakarta: Hilliana Pres, 2011).

[3] DP Ismail, Kurikulum dan Pembelajaran, (Yogyakarta: Graha Guru, 2009)

[5] Djamarah Syaiful Bahri, Psikologi Belajar, (Jakarta: Rineka Cipta, 2002)

[6] Dimyati Mudjiono, Belajar dan Pembelajaran, (Jakarta: Rineka cipta, 2009)

[7] Departemen Pendidikan dan Kebudayaan Republik Indonesia, Kamus Besar Bahasa Indonesia, (Jakarta: Balai Pustaka, 2002).

[8] Dinulilami, Belajar Al-Qur'an, http://blogspot.com.Diakses pada tanggal 11 april 2016.

[9] Departemen Agama RI, Al-Qur'an dan Terjemah (Bandung: CV Penerbit di Ponegoro)

[11] Fuad Muhammad Abdul Baqi, Al-lu’lu'Wal Marjan, Alih Bahasa: Muslich Shobir (semarang: al-ridha, 1993) 
[13] Eva Rufaidah, Hasan Bisri, Model Penelitian Agama dan Dinamika Sosial(Himpunan Rencana Penelitian), (Jakarta: Grafindo Persada, 2000)

[14] H. Mustaqim, Psikologi Pendidikan, (Yogyakarta: Fakultas Tarbiyah IAIN Walisongo Semarang, 2009)

[16] Hasibuan dan Mudjiono. Proses Belajar Mengajar, (Bandung: Remaja Rosdakarya, 2002)

[17] http://www.psikologiku.com/ Teknik Menghafal Al-Qur’an /diakses pada 11 April 2016

[18] http://www.psikologiku.com/ Teknik Menghafal Al-Qur’an /diakses pada 11 April 2016

[19] Hurlock Elizabeth B., Child development http://www.psikologiku.com/ /diakses pada 16 April 2016

[20] Hamalik Oemar, Kurikulum dan Pembelajaran, (Jakarta : Bumi Aksara, 2010), cet. Ke-10

[21] Ikhwanudin, Bakat Khusus.http//blogspot.com. Diakses pada tanggal 28 maret 2016.

[22] Mudjiono dan Dimyati, Belajar dan Pembelajaran, (Jakarta: Rineka Cipta, 2009),

[23] Nawabuddin Abdurrab, Bambang Saiful Ma`arif, Teknik Menghafal AlQur`an (Bandung: Sinar Baru,

[24] Nasution, Asas-Asas Kurikulum, (Bandung: Jamera, 1982),

[25] Nazarudin, Manajemen Pembelajaran, (Yogyakarta: Teras, 2007). 